\title{
ANALISIS KEMAMPUAN BERPIKIR TINGKAT TINGGI PADA SISWA INTROVERT DALAM MENYELESAIKAN MASALAH MATEMATIKA
}

\author{
Nur Laeli Sangadah ${ }^{1}$, Sukarmi ${ }^{2}$ \\ nurlaelisangadah2012@gmail.com, myar.log@gmail.com \\ ${ }^{1,2}$ SDIT Logaritma Karanganyar
}

\begin{abstract}
This study aims to determine the ability to higher order thinking introvert students to solve mathematics problems. This research is a qualitative research with a phenomenological approach. The subjects of this study are students of class VIII A of SMPN 2 Sruweng in the academic year of 2018/2019 totaling 2 students with the subject taken by technique using purposive. Data collection techniques used 3 methods, namely mathematics problem solving tests, field notes and interviews. The research instruments in this study were researchers, mathematics problem solving tests and interview guidelines. Techniques of analysis data used the model of Miles and Huberman which includes three steps, namely data reduction, data presentation, and drawing conclusions. The results of the study are to show the ability to think at a higher order thingking of introvert students in the aspect of analyzing intovert students able to decipher information and use the right strategy so as to obtain a correct answer. Then, in the aspect of evaluating introvert students are able to assess and draw an opinion on the decisions obtained from the results of solving problems.
\end{abstract}

Keywords: higher order thinking, introvert student, mathematical problem

\begin{abstract}
Abstrak
Penelitian ini bertujuan untuk mengetahui kemampuan berpikir tingkat tinggi pada siswa introvert dalam menyelesaikan masalah matematika. Penelitian ini merupakan penelitian kualitatif dengan pendekatan fenomenologi. Subjek penelitian ini adalah siswa kelas VIII A SMPN 2 Sruweng tahun pelajaran 2018/2019 berjumlah 2 siswa dengan teknik pengambilan subjek menggunakan purposive. Teknik pengumpulan data menggunakan 3 metode yaitu tes penyelesaian masalah matematika, catatan lapangan dan wawancara. Instrumen penelitian dalam penelitian ini adalah peneliti, tes penyelesaian masalah matematika dan pedoman wawancara. Teknik analisis data menggunakan model Miles dan Huberman yang meliputi tiga langkah yaitu reduksi data, penyajian data, dan penarikan kesimpulan. Hasil penelitian yaitu menunjukkan kemampuan berpikir tingkat tinggi siswa introvert pada aspek menganalisis mampu menguraikan informasi dan menggunakan strategi yang tepat sehingga memperoleh suatu jawaban yang benar. Kemudian, pada aspek mengevaluasi mampu menilai dan menarik sebuah pendapat atas keputusan yang diperoleh dari hasil menyelesaian soal.
\end{abstract}

Kata kunci: berpikir tingkat tinggi, siswa introvert, masalah matematika 


\section{PENDAHULUAN}

Salah satu peran penting dalam keberhasilan matematika adalah kemampuan berpikir, kemampuan berpikir dalam matematika yang harus dimiliki oleh siswa adalah kemampuan berpikir tingkat tinggi. Hal ini sesuai dengan pendapat Wang \& Wang (2014) "higher order thinking skill are an important outcome of higher education, the paper discusses the paradigms of higher order thinking in higher education in general and in businnes education". Mengingat bahwa siswa merupakan salah satu sumber daya manusia produktif sehingga perlu ditumbuhkembangkan kualitas pemikirannya untuk dapat bersaing dalam perkembangan zaman yang semakin ketat ini, maka siswa diharapkan harus memiliki kemampuan berpikir tingkat tinggi.

Kemampuan berpikir tingkat tinggi merupakan bagian dari taksonomi Bloom. Purbaningrum (2018) mengemukakan bahwa taksonomi Bloom tersusun dari enam aspek yaitu meliputi remember, understanding, apply, analyze, evaluate dan create. Menurut Wang \& Farmer (2008) kemampuan berpikir tingkat tinggi (HOTS) meliputi aspek analyze, evaluate, dan create. Jadi siswa dapat dikatakan mempunyai kemampuan berpikir tingkat tinggi jika siswa mampu mencapai aspek menganalisis, mengevaluasi dan mengkreasi dalam menyelesaikan masalah matematika.

Menurut hasil laporan lembaga internasional mengenai masalah pendidikan, indeks pendidikan Indonesia masih belum sesuai harapan yaitu berada pada urutan ke 110 dari 180 negara di dunia. Selain itu, berdasarkan data dari Education For All (EFA) Global Monitoring Report pada tahun 2011 yang dikeluarkan oleh UNESCO, indeks pembangunan pendidikan Indonesia berada pada peringkat ke-69 dari 127 (Prasetyani, dkk, 2016). Situasi ini semakin kuat dengan hasil survei Trend in International Match an Science Survey (TIMSS) sejak keikutsertaannya dari tahun 1999, peringkat siswa Indonesia belum mampu menempati posisi atas justru pada tahun 2015 Indonesia menempati peringkat ke-45 dari 48 negara (Nugroho, 2018). Salah satu penyebab rendahnya prestasi siswa ini dikarenakan lemahnya proses pembelajaran, siswa kurang didorong untuk menumbuhkembangkan kemampuan berpikirnya. Hal ini sependapat dengan hasil penelitian Kurniati, dkk (2016) \& Prasetyani, dkk (2016) tentang kemampuan berpikir tingkat tinggi (HOTS) pada siswa yang menyatakan bahwa tidak ada siswa dengan HOTS, siswa kurang mampu melakukan kemampuan analisis, evaluasi, kreasi, logika dan penalaran dengan baik. 
Hal-hal tersebut perlu dilatih dan dikembangkan oleh siswa, ketika siswa berlatih menumbuhkan melalui latihan mengerjakan soal-soal, maka siswa sebenarnya sedang berlatih menumbuhkembangkan berpikir tingkat tingginya. Soal-soal berupa analisis yang diberikan dalam pembelajaran dapat melatih kemampuan berpikir tingkat tinggi siswa. Menurut Murtafiah (2017) soal terkait berpikir tingkat tinggi mempunyai karakteristik kompleks, banyak solusi, mencakup berpikir kritis dan berpikir kreatif. Karakteristik tersebut memberikan informasi bahwa soal berpikir tingkat tinggi dapat melatih kemampuan berpikir kritis dan kemampuan berpikir kreatif. Berpikir tingkat tinggi adalah berpikir pada tingkat lebih tinggi dari pada sekedar mengingat, memahami dan menghafal atau mengatakan sesuatu kepada seseorang sama seperti sesuatu yang disampaikan (Heong, dkk, 2011).

Berdasarkan paparan tersebut, memberikan informasi terhadap kemampuan berpikir tingkat tinggi siswa. Hal demikian menunjukkan bahwa kemampuan berpikir tingkat tinggi siswa tersebut mencakup menganalisis, mengevaluasi dan menyelesaikan masalah dengan konteks cara baru. Namun dari pemaparan tersebut menyebutkan hanya dalam kemampuan kognitif siswa tanpa dikaitkan dengan kepribadian siswa.

Dalam pembentukan kemampuan berpikir tingkat tinggi, guru juga harus memahami kemampuan berpikir pada setiap kepribadian yang dimiliki siswa. Pada saat menyelesaikan masalah matematika terdapat perbedaan kemampuan berpikir yang dipengaruhi oleh faktor-faktor tertentu. Permatasari, dkk (2016) mengatakan bahwa terdapat dua faktor yang mempengaruhi kemampuan penyelesaian masalah dalam matematika. Faktor pertama terhadap diri sendiri dan kebiasaan pendidik dalam mengajar, faktor yang kedua adalah faktor tak langsung berupa motivasi dan potensi siswa.

Dari salah satu faktor tersebut, faktor tak langsung dapat mempengaruhi kemampuan berpikir dalam menyelesaikan masalah dalam matematika berupa motivasi dan potensi siswa. Potensi adalah faktor yang dimiliki siswa yang berkaitan dengan kepribadian yang dimiliki. Kepribadian yang berbeda juga dapat mempengaruhi kemampuan berpikir yang berbeda, yaitu meliputi tipe ektrovert dan tipe introvert (Suryabrata, 2005). Tipe kepribadian introvert lebih cenderung tertutup dan percaya kepada dirinya sendiri. Hal tersebut sesuai dengan pendapat Suryabrata (2005) mengatakan kepribadian introvert dipengaruhi oleh dunia subjektif berupa dunia di 
dalam dirinya sendiri yang meliputi aspek pikiran, perasaan, dan tindakan ditentukan oleh faktor-faktor subjektif.

Alwisol (2014) menguraikan bahwa gambaran dimensi individu yang termasuk kecenderungan introvert adalah memperlihatkan kecenderungan bersifat diam, teguh dalam pendirian, kemampuan kognitif relatif tinggi, teliti dan penuh pertimbangan sebelum bertindak. Permatasari, dkk (2016) dalam penelitiannya tentang proses berpikir siswa dalam memecahkan masalah matematika ditinjau dari tipe kepribadian extrovertintrovert, kepribadian introvert yang tidak dipengaruhi oleh faktor luar dapat mengubah informasi yang ada dan disesuaikan dengan pola pikir atau pemahaman serta pengetahuan yang dimiliki. Pada tahap memikirkan perkara lain, siswa yang memiliki tipe kepribadian introvert dapat mengecek dan meyakini kebenaran jawaban. Oleh karena itu, dari uraian di atas maka peneliti bermaksud untuk melakukan suatu penelitian dengan tujuan menganalisis kemampuan berpikir tingkat tinggi pada siswa introvert dalam menyelesaikan masalah matematika.

\section{METODE PENELITIAN}

Jenis penelitian ini merupakan penelitian kualitatif. Penelitian ini dilaksanakan pada bulan November-Agustus 2019 di SMP Negeri 2 Sruweng. Subjek penelitian ini adalah dua siswa kelas VIII SMP Negeri 2 Sruweng yang memiliki tipe kepribadian introvert. Menurut Satori \& Komariah (2017) menentukan subjek/objek berdasarkan tujuan tertentu disebut teknik purposive. Sehingga teknik purposive ini dalam pengambilan subjek harus berdasarkan ciri-ciri atau parameter tertentu sesuai tujuan yaitu untuk mengetahui kemampuan berpikir tingkat tinggi pada siswa introvert. Teknik pengumpulan data dalam penelitian ini meliputi: tes, wawancara, catatan lapangan dan dokumentasi. Pada soal tes tertulis materi yang digunakan adalah teorema Pythagoras yaitu sebagai berikut.

\footnotetext{
Pak Agung akan mengganti seluruh genteng di atap rumahnya. Atap tersebut berbentuk seperti gambar di bawah ini. Setiap satu meter persegi membutuhkan 10 buah genteng. Untuk mengganti genteng lama pak Agung menyediakan1000 genteng. Apakah keputusan pak Agung tersebut benar? Tunjukan alasan anda
}

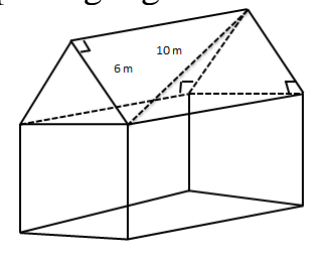


Teknik analisis data yang digunakan dalam penelitian ini adalah teknik dari Miles \& Hubermen. Satori \& Komariah (2017) menjelaskan bahwa teknik tersebut meliputi reduksi data, penyajian data dan penarikan kesimpulan. Reduksi data dalam penelitian ini yaitu memilah-milah data yang dibutuhkan dari hasil tes tertulis, catatan lapangan, wawancara, dan dokumentasi. Hasil tes kemampuan berpikir tingkat tinggi dalam menyelesaikan masalah matematika, wawancara, dan catatan lapangan ditriangulasi untuk selanjutnya dapat mendeskripsikan kemampuan berpikir tingkat tinggi dalam menyelesaikan masalah matematika. Setelah mereduksi data langkah selanjutnya adalah penyajian data.

Penyajian data dapat dilakukan dalam bentuk uraian singkat, bagan, hubungan antara kategori, flowchart dan sejenisnya (Satori \& Komariah, 2017). Selain itu, Miles dan Huberman (Sugiyono, 2013) menyatakan sebagian besar penyajian data dalam penelitian kualitatif adalah dalam bentuk teks yang bersifat naratif. Penyajian data dilakukan dengan menyajikan kumpulan data yang sudah terorganisir dan terkategori yang memungkinkan dilakukan penarikan kesimpulan. Penyajian data dalam penelitian ini terdiri atas dua tahap yaitu setelah hasil data angket kepribadian tipe introvert diperoleh, dari hasil kategori tesebut dipilih siswa sebagai subjek tes kemampuan berpikir tingkat tinggi dalam menyelesaikan masalah matematika, selanjutnya penyajian data hasil kemampuan berpikir tingkat tinggi dalam menyelesaikan masalah matematika. Dalam penelitian ini penyajian data yang dilakukan adalah memaparkan dari berbagai informasi yang telah dipilih sehingga dapat mempermudah peneliti dalam penarikan kesimpilan.

Langkah yang ketiga adalah conclusion drawing/verification yang artinya penarikan kesimpulan. Sugiyono (2013) menyatakan bahwa "kesimpulan awal yang dikemukakan masih bersifat sementara dan akan berubah bila tidak ditemukan buktibukti yang kuat yang mendukung pada tahap pengumpulan data berikutnya”. Simpulan dalam penelitian kualitatif merupakan temuan baru. Temuan yang didapat berupa deskripsi atau gambaran suatu objek yang sebelumnya masih samar-samar sehingga setelah diteliti menjadi jelas, dapat juga berupa hubungan kasual atau interaktif. Hasil yang diperoleh dalam proses analisis selanjutnya disimpulkan secara deskriptif dengan melihat data yang telah dikumpulkan dan ditemukan selama proses penelitian. 


\section{HASIL PENELITIAN}

Hasil penelitian ini mengungkap kemampuan berpikir tingkat tinggi pada siswa introvert dalam menyelesaikan masalah matematika Berikut ini dipaparkan hasil dari ketiga subjek dalam menyelesaikan masalah.

\section{Subjek LS}

Berdasarkan hasil tertulis dari penyelesaian masalah matematika yang dilakukan oleh LS, terlihat bahwa LS dapat menjawab dengan benar seperti gambar berikut.

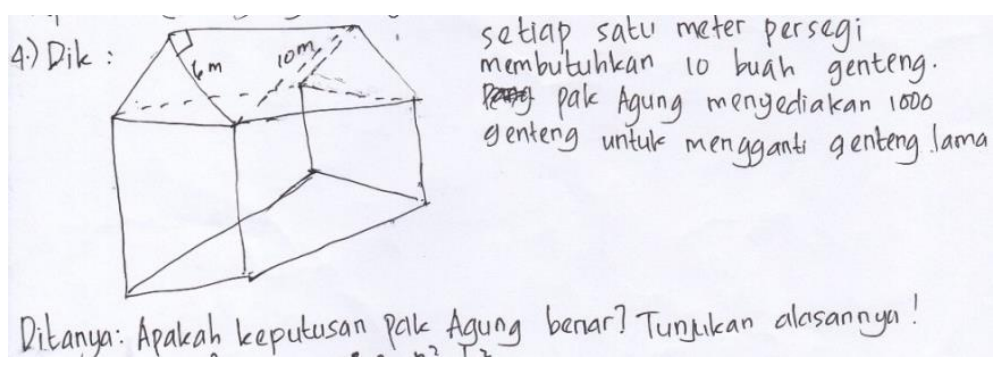

Gambar 1. Jawaban Tes Penyelesaian Masalah Matematika

Dari Gambar 1, LS mampu menguraikan informasi soal secara benar, fakta ini ditunjukkan dengan subjek LS mampu menjelaskan informasi penting dan tujuan dari soal tersebut. Dengan demikian menunjukkan sujek LS mempunyai kemampuan menganalisis. Berikut ini terlihat ketika subjek ditanya "Dari masalah tersebut informasi apakah yang kamu peroleh?" subjek menjawab "Setiap satu meter persegi membutuhkan 10 genteng untuk mengganti genteng yang sudah lama, pak Agung menyediakan seribu genteng. Apakah keputusan pak Agung benar?".

Kemudian subjek juga mampu menyusun setiap bagian-bagian permasalahan sebagai strategi untuk menyelesaian sola tersebut, seperti gambar berikut.

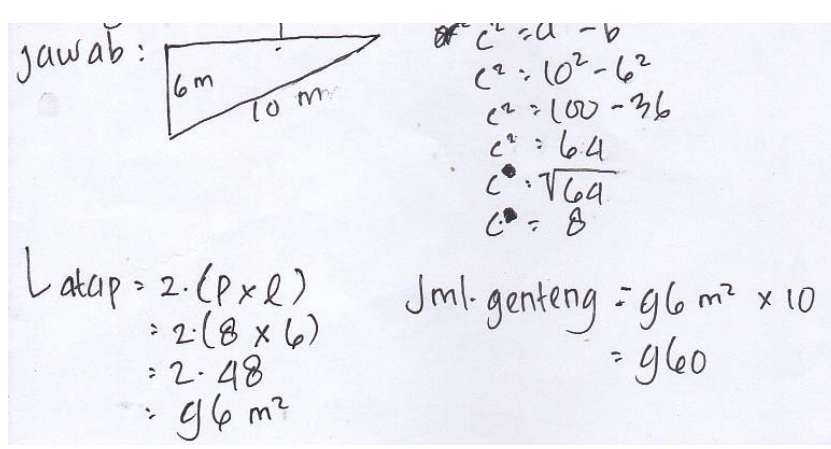

Gambar 2. Jawaban Tes Penyelesaian Masalah Matematika 
Berdasarkan Gambar 2 menunjukkan bahwa subjek mampu menunjukkan terhadap materi yang dibutuhkan untuk bisa menyelesaikan soal. Hal itu juga disampaikan pada kutipan wawancara berikut, "Bagaimanakah langkah yang kamu lakukan untuk menyelesaikan masalah tersebut?" kemudian menjawab "Pertamatama saya mencari panjang panjang atap menggunakan rumus Pythagoras". Selain itu, subjek LS juga mampu menjelaskan dengan benar terhadap proses penyelesaian dan mampu menghubungkan antar informasi soal sehingga memperoleh sebuah penyelesaian dengan benar, yaitu "Bagaimanakah langkah selanjutnya untuk memperoleh penyelesaian dari soal tersebut? Subjek menjawab "itu kan atapnya berbentuk seperti persegi panjang, kemudian saya potong menjadi dua bagian diperoleh segitiga saya cari menggunakan rumus Pythagoras yaitu $\mathrm{c}=10^{2}-6^{2}=$ $100-36=64$ berarti ketemunya 8 . Kemudian mencari luas atap $\mathrm{p} \times 1$ karena dua sisi maka $2(\mathrm{p} \times \mathrm{l})$ ketemu $96 \mathrm{~m}^{2}$. Mencari jumlah genteng yang dibutuhkan Jumlah genteng $=96 \mathrm{~m}^{2} \times 10=960$ genteng”.

Dari hasil wawancara di atas, subjek LS mampu menjelaskan proses penyelesaiannya walaupun dengan kebingungan tetapi jawabannya benar. Pertama subjek menggambar keseluruhan atap diperoleh sebuah persegi panjang, kemudian memotongnya menjadi dua bagian sehingga diperoleh segitiga siku-siku. Kemudian dengan rumus Pythagoras memperoleh semua panjang sisi segitiga siku-siku tersebut. Langkah terakhir subjek LS mencari keseluruhan luas atap untuk memperoleh jumlah genteng yang harus diganti. Disini subjek paham dan mampu menyelesaiakan soal tersebut. Hal ini menunjukkan bahwa subjek mampu menyusun strategi untuk menyelesaikan soal dan menghubungkan setiap informasi yang diperoleh dari pemahamannya memahami soal sehingga memperoleh hasil sesuai tujuan soal.

Selain itu, subjek juga mampu memutuskan pendapat dan memperoleh sebuah kesimpulan yang diperoleh antara jawaban yang diperoleh saat mengerjakan dengan sebuah pernyataan yang sudah tertera disoal, seperti gambar berikut.

$$
\begin{aligned}
& \text { jadi, keputusan yg dibuat pak Agung adalah benar. } \\
& \text { sisa } 40 \text { genteng. }
\end{aligned}
$$

Gambar 3. Jawaban Tes Penyelesaian Masalah Matematika 
Hal tersebut juga disampaikan pada kutipan wawancara berikut, "Bagaimana kesimpulan dari masalah tersebut?" subjek menjawab, "Jadi, keputusan yang dibuat pak Agung adalah benar. Sisa 40 genteng”. Hal tersebut menjelaskan bahwa subjek LS mampu memeriksa kembali jawabannya dan mengkritisi sebuah pernyataan, sehingga menunjukkan bahwa subjek LS mempunyai kemampuan mengevaluasi.

\section{Subjek MFA}

Berdasarkan data diperoleh, menunjukkan bahwa subjek MFA mampu dalam memahami materi yang berhubungan dengan soal yang sedang dihadapi. Selain itu subjek MFA juga menguraikan informasi yang dibutuhkan untuk mengerjakan soal tersebut, seperti yang disampaikan ketika subjek ditanya "Dari masalah tersebut informasi apa yang kamu peroleh?" kemudian subjek menjawab "Pak Agung akan mengganti seluruh genteng. Setiap satu meter persegi membutuhkan 10 genteng untuk mengganti genteng yang sudah lama pak Agung menyediakan seribu genteng kemudian yang ditanyakan apakah keputusan pak Agung benar? Tunjukkan alasannya!. Selanjutnya saya pertama-tama dengan rumus Pythagoras saya mencari panjang atap diperoleh 8 dari tripel Pythagoras dari yang diketahui di soal yaitu 6 dan 10 dari bagian atap yang berbentuk segi empat kemudian saya potong jadi dua bagian sehingga diperoleh 8 meter. Lalu yang saya tahu dari soal lebarnya adalah 6 meter". Kutipan wawancara tersebut menunjukkan bahwa subjek MFA mampu menguraikan informasi dan mampu menghubungkan pengetahuan yang dipelajari sebelumnya. Kemudian dapat dilihat juga seperti gambar berikut.

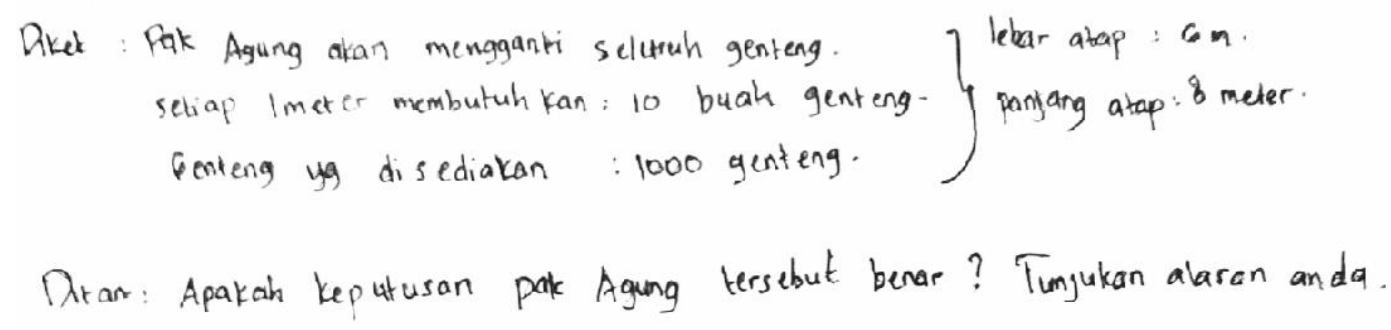

Gambar 4. Jawaban Tes Penyelesaian Masalah Matematika

Gambar 4 menunjukkan bahwa subjek MFA mampu menguraikan informasi penting yang digunakan untuk menyelesaikan soal tersebut. Subjek MFA lebih cenderung menggunakan pengalaman dan pengetahuan sesuai yang sudah dipelajari 
sebelumnya.

Selanjutnya subjek mampu menjelaskan proses penyelesaiannya. Hal tersebut dapat dilihat bahwa subjek MFA menyusun strategi dari informasi yang diperoleh dari gambar pada soal, seperti gambar berikut.

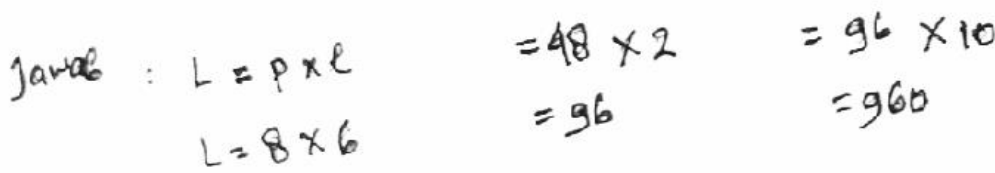

$$
\begin{aligned}
& =48
\end{aligned}
$$

Gambar 5. Jawaban Tes Penyelesaian Masalah Matematika

Dari Gambar 5 tersebut menunjukkan bahwa subjek MFA mampu menggunakan strategi yang digunakan untuk menyelesaiakan soal, paham terhadap strategi yang akan digunakan. Selain itu subjek juga mampu menjelaskan langkah penyelesaian soal tersebut, seperti ketika subjek MFA diminta untuk menjelaskan penyelesaiannya yang terdapat pada kutipan pernyataan subjek berikut, "Apakah langkah selanjutnya untuk menyelesaikan soal tersebut?” subjek menjawab "Mencari luas atap yaitu $p \times l$ karena dua sisi saya kalikan dua hasilnya sehingga memperoleh 96. Jumlah genteng $=96 \times 10=960$ genteng”. Berdasarkan paparan tersebut, bahwa Subjek MFA mampu menguraikan informasi dengan memilih informasi yang penting yang berkaitan dengan penyelesaian kemudian menyusun strategi penyelesaian dan mampu menghubungkan dengan pengalaman serta pengetahuan yang dimiliki berdasarkan pemahamannya. Dengan demikian menunjukkan sujek MFA mempunyai kemampuan menganalisis.

Selain itu, subjek juga mampu memutuskan pendapat dan memperoleh sebuah kesimpulan yang diperoleh antara jawaban yang diperoleh saat mengerjakan dengan sebuah pernyataan yang sudah tertera di soal, seperti gambar berikut.

$$
\begin{aligned}
& \text { Benar, karena genteng yang dibutuhican untuk mongganti genteng rumah pak Agung } \\
& 960 \text { buah genteng. }
\end{aligned}
$$

Gambar 6. Jawaban Tes Penyelesaian Masalah Matematika

Hal tersebut juga disampaikan pada kutipan wawancara berikut, "Bagaimana kesimpulan dari masalah tersebut?" subjek menjawab, " Benar, karena genteng yang dibutuhkan untuk mengganti genteng rumah pak Agung 960 buah genteng Benar, 
karena genteng yang dibutuhkan untuk mengganti genteng rumah pak Agung 960 buah genteng". Hal tersebut menjelaskan bahwa subjek MFA mampu memeriksa kembali jawabannya dan mengkritisi sebuah pernyataan, sehingga menunjukkan bahwa subjek MFA mempunyai kemampuan mengevaluasi.

\section{PEMBAHASAN}

Pembahasan mengenai kemampuan berpikir tingkat tinggi pada siswa introvert dalam menyelesaikan masalah matematika pada materi teorema Pythagoras pada penelitian ini yaitu, siswa introvert mampu menguraikan dan memilih bagian yang memiliki hubungan dengan mencari dan menentukan berapa banyak genteng diharus digunakan untuk mengganti seluruh bagian atap rumah dengan genteng yang sudah di sediakan sejumlah 1000, setiap satu meter persegi membutuhkan 10 genteng. Kemudian mendiskriminasi informasi yang tidak sesuai pada masalah terkait teorema Pythagoras. Selanjutnya, pada tahap merencanakan dan melaksanakan penyelesaian masalah siswa introvert mampu menguji sebuah pernyataan (apakah keputusan benar jika sudah menyediakan 1000 genteng). Lalu siswa intovert memisalkan satu bagian atap dengan sebuah persegi panjang dengan lebar $(l)=6 \mathrm{~m}$, dan memotong menjadi dua bagian diperoleh sebuah segitiga siku-siku. Segitiga siku-siku tersebut dikaitkan dengan persamaan Pythagoras yaitu $c^{2}=a^{2}-b^{2}$, dengan $a=10$ dan $b=6$ sehingga diperoleh $c=8$ yang merupakan panjang (p) persegi panjang tersebut. Selanjutnya diperoleh $\mathrm{L}_{\text {atap }}=2 \times(p \times l)$.

Hal tersebut menunjukkan bahwa siswa introvert mampu menguraikan informasi yang dipahami dan menghubungkan dengan strategi yang tepat sehingga memperoleh sebuah penyelesaian yang benar. Sesuai dengan hasil penelitian dari Permatasari, dkk (2016) yang mengatakan bahwa pada tahap menemukan jawaban (find an answer) siswa dengan kepribadian introvert ini dapat menyelesaikan masalah berdasarkan metode yang telah diketahui sebelumnya. Siswa introvert mampu menguraikan informasi dan menggunakan strategi yang tepat sehingga memperoleh suatu jawaban yang benar, hal itu menunjukan bahwa siswa introvert mampu mencapai kemampuann menganalisis. Hal ini sesuai penelitian dari Purbaningrum (2017) yang mengatakan bahwa kemampuan menganalisis yaitu mampu memeriksa dan mengurai informasi yang masuk dan membagi-bagi atau menstrukturkan informasi ke dalam bagian yang lebih 
sederhana untuk mengenali pola atau hubungan yang ada dan memformulasikan masalah.

Kemudian, tahap memeriksa kembali dimana siswa introvert mampu menilai sesuai hasil yang diperoleh dari penyelesaian soal dan menarik sebuah pendapat atas keputusan berdasarkan masalah teorema Pythagoras yang telah ditemukan yaitu $\mathrm{L}_{\text {atap }}=$ $2 \times(p \times l)=96 \mathrm{~m}^{2}$. Kemudian Jumlah genteng $=96 \times 102=960$. Siswa introvert mampu menunjukkan keputusan benar karena jumlah genteng yang disediakan 1000 genteng digunakan 960 genteng dan sisa 40 genteng. Hal tersebut menunjukkan bahwa siswa introvert telah mampu mencapai kemampuan mengevaluasi. Menurut Purbaningrum (2017), kemampuan mengevaluasi ditunjukkan apabila siswa mampu menganalisis infomasi dengan tepat, memahami maksud pertanyaan dengan benar, serta memberikan alasan/bukti yang akurat.

Berdasarkan paparan tersebut, siswa introvert mampu mencapai aspek kemampuan menganalisis dan mengevaluasi. Aspek-aspek tersebut menunjukkan bahwa siswa introvert mampu berpikir tingkat tinggi. Purbaningrum (2017) menyebutkan bahwa salah satu siswa dikatakan mampu berpikir tingkat tinggi jika mampu berpikir pada tahap menganalisis dan mengevaluasi.

\section{SIMPULAN DAN SARAN}

Berdasarkan analisis data dan hasil pembahasan yang telah diuraikan peneliti, maka diperoleh simpulan yaitu kemampuan berpikir tingkat tinggi pada siswa introvert. Siswa introvert pada aspek menganalisis mampu menguraikan informasi dan menggunakan strategi yang tepat sehingga memperoleh suatu jawaban yang benar. Kemudian pada aspek mengevaluasi siswa introvert mampu menilai dan menarik sebuah pendapat atas keputusan yang diperoleh dari hasil menyelesaian soal.

Beberapa saran yang dapat peneliti sampaikan, untuk guru hendaknya perlu mengetahui seberapa jauh kemampuan berpikir tingkat tinggi siswa dan mengembangkan pembelajaran yang disesuaikan dengan tipe kepribadian yang dimiliki siswa untuk dapat menumbuhkan kemampuan berpikir tingkat tinggi. Kemudian untuk peneliti lain, sebaiknya mengkaji lebih lanjut terkait berpikir tingkat tinggi dalam menyelesaikan masalah matematika dengan subjek yang lebih bervariasi dan materi 
berbeda. Selain itu perlu dilakukan penelitian yang serupa agar dapat memperkuat hasil penelitian.

\section{DAFTAR PUSTAKA}

Anggraeni, M., Husain, A. N., \& Arifin, S. 2014. Hubungan Tipe Kepribadian Introvert dengan Kecanduan Internet pada Siswa Kelas X di SMA N 1 Banjarmasin. Berkala Kedokteran. https://www.neliti.com/id/publication s/59974. Pada hari Senin, 22 oktober 2018 pukul 19:21.

Dinni, H. N. 2018. HOTS (High Order Thinking Skills) dan Kaitannya dengan Kemampuan Literasi Matematika. Prisma, Prosiding Seminar Nasional Matematika. https://journal.unnes.ac.id/sju/index.php/prisma/. Pada hari Kamis, 14 maret 2019 Pukul 15: 40.

Heong, Y. M., Othman, W. B., Yunos, J. B. M., Kiong, T. T., Hassan, R. B., \& Mohaffyza, M. 2011. The Level of Marzano Higher Order Thinking Skills Among Technical Education Students. International Journal of Social Science and Humanity. ijssh.org/papers/20-H009.pdf. Pada hari Senin, 7 Januari 2019 pukul 15: 01 .

Murtafiah, W. 2017. Profil Kemampuan Berpikir Kreatif Mahasiswa dalam Mengajukan Masalah Persamaan Diferensial. Jurnal Iimiah Pendidikan Matematika. https://www.researchgate.net/publication/318058304. Pada Jum.at, 23 November 2018 pukul 09:42.

Nugroho, R. A. 2018. HOTS (Kemampuan Berpikir Tingkat Tinggi: konsep, pembelajaran, penilaian, dan soal-soal). Jakarta: PT Gramedia Widiasarana Indonesia.

Permatasari, N., Budiyono, \& Slamet, I. 2016. Proses Berpikir Siswa Kelas VII SMP Negeri 25 Surakarta dalam Memecahkan Masalah Matematika Ditinjau dari Tipe Kepribadian Extrovert-Introvert pada Materi Persamaan Garis Lurus. Jurnal Elektronik Pembelajaran Matematika. http://jurnal.fkip.uns .ac.id. Pada Jum'at, 26 Oktober 2019 pukul 21:24.

Prasetyani, E., Hartono, Y., \& Susanti, E. 2016. Kemampuan Berpikir Tingkat Tinggi Siswa Kelas XI Dalam Pembelajaran Trigonometri Berbasis Masalah di SMP Negeri 18 Palembang. JURNAL GANTANG Pendidikan Matematika FKIP UMRAH. https://ojs.umrah.ac.id./index.ph p.ga\%20ntangntang/ar ticle/view/4. Pada hari Minggu, 14 Oktober 2018 pukul 14:59.

Purbaningrum, K. A. 2017. Kemampuan Berpikir Tingkat Tinggi Siswa SMP dalam Pemecahan Masalah Matematika Ditinjau dari Gaya Belajar. Jurnal Penelitian dan 
https://jurnal.untirta.ac.id/index.Php/JPPM/article/view/2029/0. Pada Hari Selasa, 12 Maret 2019.

Satori, D. \& Komariah. 2017. Metodologi Penelitian Kualitatif. Bandung: Alfabeta.

Sugiyono. 2013. Metodologi Penelitian Pendidikan Pendekatan Kuantitatif, Kualitatif, dan $R \& D$. Bandung: Alfabeta.

Suryabrata, S. 2005. Psikologi Kepribadian. Jakarta: PT Raja Grafindo Persada.

Wang, V. \& Farmer, L. 2008. Adult Teaching Methods in China and Bloom's Taxonomy. International Journal for the Scholarship of Teaching and Learning. https://digitalcommons.georgiasouthern.edu/cgi/viewcontet.cgi? article=1107\&co ntext=ij-sotl. Pada hari Kamis, 13 Desember 2018 pukul 10:24.

Wang, H. \& Wang, S. 2017. Teaching And Learning Higher Order Thinking. International Journal of Arts \& Sciences. http://universitypublications.net lijas/0702/pdf/H4V240.pdf. Pada hari Selasa, 16 Oktober 2018 pukul 20:44. 